\title{
Quantifying the Trade Effects of Sanitary and Phytosanitary Regulations of the Eu on Sudan's groundnuts Exports
}

\author{
Eltighani Elamin*, Sitana Elrasheed and Samar Abdallah \\ Agricultural Economics and Policy Research Center, Sudan
}

Submission: July 05, 2017; Published: July 21, 2017

"Corresponding author: Eltighani Elamin, Postgraduate and Assistant Professor at the Agricultural Economics and Policy Research Center, Khartoum North, Sudan, Tel: +249912175479; Email: eltighani@yahoo.com

\begin{abstract}
A growing concern over health risks associated with food products has prompted revisions in Sanitary and Phytosanitary Standards (SPS) in industrialized countries. The SPS agreement under WTO defined its standards as measures taken to protect human, animal and plant health from risks associated with imported agricultural commodities. Sudan is characterized by heavy reliant on agricultural activities in terms of food, contribution to GDP, agro-processing, employment, and export earnings. Groundnuts is an oilseed and second most important agricultural export commodity, groundnuts have characterized by annual fluctuations and decline in quantities imported by the EU. This study has employed a gravity-equation model to estimate the impact of changes in differing levels of standards based on the EU standard and those suggested by international standards, using trade and regulatory data for European countries and Sudan during 1980-2010. The results suggest that the implementation of the new aflatoxin standard in the EU is significantly reduced Sudan exports of groundnuts to Europe; trade elasticity of aflatoxin standard is -0.201 and statistically significant. Moreover, the simulation results based on the assumption that these EU countries adopt the total aflatoxin level recommended by CODEX show that Sudan would have gained an estimated expectation of groundnuts export earnings as many as 1752 times or more from its exports to these countries from 1980 to 2010.
\end{abstract}

Due to the stringent standards applied by these countries, however, this percentage amount represents the forgone export revenue for Sudan. These findings support the hypotheses that stringent SPS standards are limiting, in general, agricultural trading markedly. The EU standard, which would reduce health risk by approximately 1.4 deaths per billion a year, will decrease Sudan exports by approximately 1000percentin contrast to regulation set at an international standard. Finally, the study concluded with the need for technical and financial assistance to Sudan to help match the requirements imposed by SPS measures. A further conclusion, set in relation to the external promotion policy package for groundnuts export, internal policies need to endorse by policy makers, to support strengthening the agricultural sector.

Keywords: Agro-processing; Annual fluctuations; Financial assistance

\section{Introduction}

One of the most important problem encountered in marketing of agro-food products is the problem of specification and quality control emanating from liberalization of agricultural trade and agreements of the World Trade Organization (WTO). The exporting countries have to follow the set of rules and regulations specified by the regulatory WTO. In case of non-fulfillment of the exact specified regulations, there is a high probability of rejection by the importing country. However, the WTO noted that SPS measures could be very effective in protectionism due to its being technical and deceptive [1]. Various studies have shown that SPS measures have reduced the volume of exports of selected agro-based products in developing countries [2] Hence, because of increasing concerns on food safety, stricter SPS requirements in trade, competitiveness in export markets and occasionally protectionism, trade in agricultural products faces significant problems satisfying SPS.

Aflatoxins are a group of structurally related toxic compound, a naturally occurring mycotoxin produced by two species of fungi that contaminate certain foods and result in the production of acute liver carcinogens in the human body. They discovered in 1960 following the death of over 100,000 turkeys in the United Kingdom and high incidences of liver disease in ducklings in 
Kenya and hatchery trout in the United States. Aflatoxins found in groundnuts, cottonseed, corn, soybean meal, fishmeal and other grains seed and feed (U.S.A Food and Drug Administration, 2000). In Sudan aflatoxins problem first realized and studied systematically in 1971 when certain Sudanese groundnuts consignments been rejected (as exports) due to aflatoxin contamination. The contamination with aflatoxin can cause economic loss to farmers and merchants, national losses through export reduction; thus, frequent occurrence of these toxins in agricultural commodities has a potential of negative impact on the economies of the affected regions, especially in developing countries, where harvest and post-harvest techniques are not adequate to prevent aflatoxin contamination. Trade issues continue to be a significant barrier for Sudan groundnuts exports in certain destination markets. More specifically, SPS barriers, related to Aflatoxin, limit or prohibit groundnut exports to some countries.

Groundnuts are an oilseed crop, which has considered as one of the important cash crops in Sudan. In 1970s, it ranked second to cotton and recently it was first of the list of exports in terms of total value of exports. In addition, Sudan has for long known as one of the major groundnuts exporter, occupying the second place in 1975 after USA and the shelled groundnuts of Sudan represented $27 \%$ of world market in 1976.

Table 1: Sudan's Exports of Groundnuts from Season 1980/1981 to Season 2009/2010 (Quantities in tons). Source: Ministry of Agriculture and forestry, Ministry of foreign trade, 2010.

\begin{tabular}{|c|c|c|c|c|c|}
\hline Season & Season & Season & Season & Season & Season \\
\hline 1980 & 1980 & 1980 & 1980 & 1980 & 1980 \\
\hline 1981 & 94300 & 1991 & 2526 & 2001 & 17250 \\
\hline 1982 & 89000 & 1992 & 1946 & 2002 & 13157 \\
\hline 1983 & 18000 & 1993 & 14432 & 2003 & 376 \\
\hline 1984 & 22500 & 1994 & 6213 & 2004 & 3182 \\
\hline 1985 & 13300 & 1995 & 4642 & 2005 & 3214 \\
\hline 1986 & 1100 & 1996 & 2176 & 2006 & 343 \\
\hline 1987 & 7880 & 1997 & 14782 & 2007 & 1167 \\
\hline 1988 & 69000 & 1998 & 25440 & 2008 & 842 \\
\hline 1989 & 5700 & 1999 & 407 & 2009 & $\begin{array}{c}\text { No } \\
\text { export }\end{array}$ \\
\hline
\end{tabular}

Nevertheless, groundnuts export's (quantity, value) and its share in total Sudan's exports showed continuous fluctuations since the mid of 1980s and its exports dropped steadily during the last decades. Table 1 shows exports of groundnuts. On average, groundnuts accounted for about $7 \%$ in 1980 s and $1 \%$ in 1990 s of total exports compared to $0.08 \%$ in 2000 s. The deterioration and fluctuation of groundnuts in terms of exports performance attributed to many factors, the most important are fluctuations in the domestic production of groundnuts in recent years, variability of the price in both world and domestic markets, lack of production and export credit, lack of marketing and exporting services and high production costs and falling world prices. The gradual growth of groundnuts local consumption at different forms (roasted, confectionaries or as oil) was another factor that might have negative effect on groundnuts export. All these factors affect groundnuts competitiveness and export revenues negatively. In addition, the decline in the export of groundnuts can partly explained by the specific conditions in Sudan (weak management and ineffective irrigation schemes). Barriers to export due to aflatoxin infection are the other reason, which led to reduction of quantities from groundnuts exports (Trade Champers Union, 2009).

Table 2: Sudanese Groundnuts Percentage Market Share in EU Market (Five-year Average of EU Groundnuts Imports). Source: Calculations based on UNCTAD database.

\begin{tabular}{|c|c|c|c|c|c|c|c|}
\hline $1972-$ & $1972-$ & $1972-$ & $1972-$ & $1972-$ & $1972-$ & $1972-$ & $1972-$ \\
1975 & 1976 & 1977 & 1978 & 1979 & 1980 & 1981 & 1982 \\
\hline $90 \%$ & $85 \%$ & $71 \%$ & $\begin{array}{c}21 . \\
30 \%\end{array}$ & $6 \%$ & $9 \%$ & $5 \%$ & $0.60 \%$ \\
\hline
\end{tabular}

Western Europe is the major destination for groundnuts exports from Sudan as shown in Table 2. Sudan's exports are likely, therefore, be affected strongly by regulatory reforms in European import markets. Groundnuts exports to the EU have to satisfy a series of stringent public and private food quality and safety standards, which put pressure on groundnuts exporters in Sudan to stay up to date with the changing legislation and private standards.

According to Trade Champers Union (2009), Sudanese share in world and EU groundnuts market illustrates a fluctuating and deteriorating position of Sudanese groundnuts competitiveness and market access in face of an increasing international groundnuts market. Apart from the domestic prices and other policy distortions facing production, the existence of market restrictions in importing countries constrain the present and expected expansion of groundnuts export from the Sudan into the world.

In addition, these trade barriers to Sudan groundnuts limit the amount of Sudan exports or impose additional costs on Sudan groundnuts producers and exporters, imply higher risk of crop wastage and crop failure, exclusion of small growers and small exporters from the supply chain and export chain and thereby reducing Sudan's revenue from the groundnuts industry. Until 1997, members of the European Union implemented different standards for aflatoxins in foodstuffs. The stringency of the standards varied across countries. In July 1998, the commission's directive has established the total aflatoxin standard in groundnuts subject to further processing at $15 \mathrm{ppb}$ (8 ppb for B1) in other nuts and dried fruits subject to further processing at $10 \mathrm{ppb}$ (5ppb for B1). It has also established a more stringent standard on cereals and dried fruits and nuts intended for direct human consumption at $4 \mathrm{ppb}$ ( $2 \mathrm{ppb}$ for B1). According to the directive, the EU members are to implement the 
necessary laws to comply with the new standards no later than 31 December 2000 (Table 3).

Table 3: Variables Used in the Model. *Trade data includes bilateral trade value across time for the period (1980-2010).

\begin{tabular}{|c|c|}
\hline Dependent Variables & Abbreviations \\
\hline $\begin{array}{c}\text { Natural Log of trade value from } \\
\text { Sudan i to EU country member } \mathrm{j}\end{array}$ & Ln Tij \\
\hline
\end{tabular}

This study sought is a twofold objective:

A. Assesses the impact of present trade barriers, through calculating the trade effects of EU aflatoxin standards on exports value of Sudanese groundnuts during (1980-2010).

B. Assesses effects of the new market access opportunities, under reduced trade barriers scenarios on groundnuts exports earnings of Sudan. That is Codex sanitary and phytosanitary (SPS) standards versus standards adopted by EU importing countries.

\section{Methodology}

\section{Gravity model}

Hillman (1991) defines a non-tariff barrier (NTB) as "Any governmental device or practice other than a tariff which directly impedes the entry of imports into a country and which discriminates against imports, but does not apply with equal force on domestic production or distribution." Thornberry et al. [3] endorse this concept; their definition includes standards of identity, measure\& quality, SPS measures, and packaging measures. The gravity method is flexible enough to describe and analyze a wide range of (SPS) measures, once enough information gathered on the measure itself. Furthermore, an analyst can implement this model through single equation econometric methods to provide estimates of effects and ideally provides a simple modeling structure into which to place empirical data for the calculation of the trade impacts. Finally, this model extends the capacity of traditional economic tools (i.e. regression approach) with which international economists are well familiarized in order to evaluate the impact of non-traditional type of "potential trade barriers". Head (2000) summarizes the basic principles of gravity models; Gravity Models rely on Newton's "Law of Universal Gravitation" formula, which holds the attractive force between two objects i and j, given by:

$$
F i j=G^{*}\left(M i^{*} M j\right) / D i j 2
$$

Where $M_{i}$ and $M_{j}$ correspond to the masses of objects $I, j, D_{i}$ is the distance between the two objects, and $\mathrm{G}$ is a gravitational constant. In a similar way, economists are using this equation to explain trade flows with Fij denotes the "flow" from origin i to destination $\mathrm{j}, \mathrm{M}_{\mathrm{i}}$ and $\mathrm{M}_{\mathrm{j}}$ denote the relevant economic sizes of the two locations and $\mathrm{D}_{\mathrm{ij}}$ denoting the distance between the locations. G, a, b and c being constant, yielding: The Newton's Law-based, first specification for normal trade in non-linear form as follows:

$$
\text { Fij }=G^{*}\left(M_{i a *}{ }^{M j b}\right) / D i j c
$$

Which is the Tinbergen (1962) version of the gravity equation $(\mathrm{G}, \mathrm{a}$, and $\mathrm{b}$ have subsequently been related to the form of economic functions).As mentioned earlier, in applied work, the model often extended by including variables to account for language relationships, tariffs, contiguity and access to sea, colonial history, exchange rate regimes and other variables of interest (Table 4).

\begin{tabular}{|c|c|}
\hline Independent Variables & Abbreviations \\
\hline Natural Log of Sudan's population & Ln Pi \\
\hline Natural Log of importing country's population & $\operatorname{Ln} \mathrm{Pj}$ \\
\hline Natural Log of real Sudan's GDP & Ln GDPi \\
\hline Natural Log of importing country's GDP & LnGDPj \\
\hline Natural Log of distance between both countries & Ln Dij \\
\hline $\begin{array}{l}\text { Natural Log of the total aflatoxin standard of } \\
\text { importing country imposed on food product }\end{array}$ & Ln TAFj \\
\hline $\begin{array}{l}\text { Natural Log of FOB price (free on board) in Dollar } \\
\text { per Ton }\end{array}$ & Ln FOBi \\
\hline Natural Log of production of Groundnuts in Sudan & Ln Yi \\
\hline $\begin{array}{l}\text { Natural Log of Domestic consumption of } \\
\text { Groundnuts in Sudan }\end{array}$ & Ln Dc \\
\hline Natural Log of official exchange rate & Ln EO \\
\hline $\begin{array}{l}\text { Dummy variables for Government Effect (Before } \\
\text { and After Salvation Economic Liberalization Policy) }\end{array}$ & 1,0 \\
\hline $\begin{array}{l}\text { The term is the error term captures the effect of } \\
\text { unobserved factors and is assumed to be normally } \\
\text { distributed with mean zero }\end{array}$ & Eij \\
\hline
\end{tabular}

Table 4: Variables used in the model.

An interesting application of the method estimates how much trade foregone only because of the "border" effect. For example McCallum (1995) showed that in 1988 the US - Canadian border led to an effect that all things being equal (in particular distances and costs), intra-Canadian province trade was 22 times higher than trans-border trade. Since that controversial study, numerous attempts made to include some explanatory variables in the analysis, including language, indicators of "remoteness," cultural differences, etc. Language and cultural assimilation, historical trade relationships may have created strong dependency on the market in countries that had colonial ties, these factors can possibly appear as nonmarket barriers and separating their effect from the predicted results is necessary [4].

The authors have introduce Dummy variables to deal with various types of local characteristics and to control for unobserved factors such as production environment, product quality and different policy settings as well. However, administrative barriers have seldom taken explicitly into consideration. It seems possible to introduce as explanatory variables, information on regulations. Gravity based techniques 
attempt to measure the trade impact of non-trade barriers (NTBs), rather than their welfare impact, and may therefore ignore some of the effects that the regulations have to correct market failures but restrict trade. However, the sign of the variables that capture the non-trade barriers (NTBs) effect in the regression is not constrained, and it is possible to capture the trade enhancing effect of regulations, when they act as standards that facilitate trade [5-8]. Economist often distinguish four groups of studies: surveys, case studies, computable general equilibrium models and econometric models. Gravity models estimate only trade effects, and equilibrium models only account for the effects of supply and demand changes. Given the heterogeneous nature of these regulations, a unifying methodology does not exist (Deard off, 1998).

\section{Empirical analysis and model specification}

The empirical analysis will present an econometric method to measure the effect of standards and other variables on the trade flows, measurement in economics attempts to capture complex effects into one scalar. Measures of NTBs based on how a given regulation affects the overall volume of imports and exports. Taking as example the aflatoxins standards and trade in groundnuts between EU and Sudan, this is a direct attempt to tackle the problem of empirically "quantifying" the impact of some specific regulations on international exchange, which is clearly a first step towards the objective of evaluating the tradeoff posed by the introduction of standards. The specification of our model depends on many considerations. Some related to selection of exogenous (independent) variables that assumed to influence variability of the dependent variable. Specification of any economic model, according to Heady and Dillon (1961) requires first: a single equation set of system appropriate equation; secondly, relevant set of variables have chosen and thirdly, a test of hypothesis has done in an appropriate algebraic form of equations $[9,10]$.

The author have modified the standard gravity equation model by introducing or including additional variables as explanatory variables to deal with various types of local characteristics and reflect the main factors affecting crop exports [11]. The model then expected to improve significantly by incorporating these variables.

It often argued that, the main factors influence crop's international competitiveness is yield, international price, cost structure of the commodity system and the exchange rate. The function applied after it has transformed to logarithm form by converting all variables both inputs and the output into their equivalent logarithm. Regression coefficients estimated, determine the nature of returns to scale, which would indicate the percentage increase in output that will result from one percent increase in the input i.e. constant returns to scale. Regression variables that mostly incorporated in a standard gravity equation are included in the specified model used in this study for estimating the impacts of SPS measures on agricultural export. Hence, the specification of the gravity model, which applied in this thesis, holds the following functional form (Table 5).

Table 5: Summary of the Empirical Findings and Results of the Gravity Regression.

\begin{tabular}{|c|c|c|c|c|c|c|}
\hline \multicolumn{7}{|c|}{ Estimation Results for Pooled EGLS Model (Gravity Equation Final Result) } \\
\hline Dependent Variable & Predictors Entered & Method & R square & F-statistic value & Prob. (F-statistic) & Decision \\
\hline \multirow{17}{*}{ LOG(N) } & LOG(OE) & \multirow{17}{*}{$\begin{array}{l}\text { Pooled EGLS } \\
\text { (Period } \\
\text { weights) }\end{array}$} & \multirow{17}{*}{0.9779} & 324140.6 & 0 & \multirow{17}{*}{$\begin{array}{l}\text { The model fits the } \\
\text { data, i.e. variables } \\
\text { that entered the } \\
\text { model reflect a } \\
\text { real relationship } \\
\text { between them and } \\
\text { the groundnuts } \\
\text { total export value } \\
\text { or affect it. }\end{array}$} \\
\hline & DUM & & & & $<0.0005$ & \\
\hline & LOG(AF) & & & & & \\
\hline & LOG(POP_SUD) & & & & & \\
\hline & LOG(FOB) & & & & & \\
\hline & LOG(DC_SUD) & & & & & \\
\hline & LOG(Y_SUD) & & & & & \\
\hline & LOG(D_BEL) & & & & & \\
\hline & LOG(D_BUL) & & & & & \\
\hline & LOG(D_FR) & & & & & \\
\hline & LOG(D_GB) & & & & & \\
\hline & LOG(D_GER) & & & & & \\
\hline & LOG(D_GR) & & & & & \\
\hline & LOG(D_IT) & & & & & \\
\hline & LOG(D_NL) & & & & & \\
\hline & LOG(D_POR) & & & & & \\
\hline & LOG(D_SW) & & & & & \\
\hline \multicolumn{4}{|c|}{ Durbin-Watson stat 2.219106} & \multicolumn{3}{|c|}{ Note $*$ is level of significance at $5 \%$} \\
\hline
\end{tabular}


Ln Tij $=b_{0}+b_{1} \operatorname{Ln} G D P i+b_{2} \operatorname{LnGDPj}+b_{3} \operatorname{Ln} D i j+b_{4} \operatorname{Ln} P i+b_{5}$ $\operatorname{Ln} \mathrm{Pj}+\mathrm{b}_{6} \operatorname{Ln} \mathrm{TAFj}+\mathrm{b}_{7} \operatorname{LnFOBi}+\mathrm{b}_{8} \operatorname{Ln~Yi}+\mathrm{b}_{9} \operatorname{Ln} \mathrm{Dc}+\mathrm{b}_{10} \operatorname{Ln} \mathrm{EO}+$ $\mathrm{b}_{11}$ Dummy + eij

The above equation presents the classical double-log specification that normally used to estimate the gravity type models and has the immediate advantage that the estimated coefficients coincide with the response elasticity. The value of Sudan's groundnuts exports is regressed against EU aflatoxin measures along with other several natural variables (e.g. geographic distance) and policy variables (e.g. FOB prices), that promote or divert trade in order to isolate the impact of standards on trade. Referring to the variables chosen the authors decided not to include the dummy indicators of common border, cultural proximity (language), although these variables can possibly appear as non-market barriers and separating their effect from standards is necessary. Nevertheless, as the pairs of trading partners do not share a common culture or border, it does not appear to have important implications for the predicted results. However, as some observations for endogenous variable assume the value of zero, this cause a problem for the logarithmic transformation. In order to deal with this issue the authors have substituted these zero values for small values instead of simply disregarding them (Winters and Soloaga, 2001; Wang and Winters, 1994).

It well known that many developing countries discriminate against agriculture whereas developed ones support their farmers. Domestic policies should be design to reduce production and marketing costs that would further reduce the export price and enhanced increased groundnuts exports volume. In this model, it has assumed that the value of groundnuts exports from the Sudan positively related to the FOB price. The regression analysis of this study based on panel data. The data used covered the period from 1980 to 2010 and it obtained from secondary sources. The analysis focuses on the estimation of the regression coefficients (constant elasticity). In particular, will they be positive or negative, large or small. The slope coefficients of the equation measure the variables elasticity, because the estimated equation is in log mathematic form [12].

\section{Simulation applying CODEX recommended standard of aflatoxin on sudan's}

Groundnuts exports: Once authors have obtained the estimated (SPS) coefficient, they used it to calculate and simulate the potential export revenue gains and losses with different standards. The CODEX has set total aflatoxin level, which is more lenient than most EU countries. In order to estimate the Sudan's groundnuts trade flow that would have occurred if the countries considered in the study were adopting the CODEX standard that, if the EU standard consistent with those of international standard-setting bodies such as the Codex aliment Arius measures, a simulation was done on the final model. The simulation methodology helps to assess the difference between the groundnuts trade flow that would have occurred by adopting the total aflatoxin level recommended by CODEX and the trade flow using EU standards. The predicted trade flow in value under this scenario computed for Sudan's export of groundnuts [1315].

Codex comparison: Comparison between predicted trade flows with the CODEX standard and EU standards provides some indication of the trade restrictiveness of these barriers. In addition, it simulates the effects of various policy interventions on the exportability of Sudan major agricultural commodities and helps understand how important these constraints are for different crops. Further, it provides results on how trade flows between Sudan and Europe would differ under conditions in which (1) using codex standard (2) using the new European harmonized standard imposed on Sudan's Groundnuts exports, since 1989; which exceed the recommendations of standards setting bodies.

\section{Results and Discussion}

Table 5 summarize the empirical findings and econometric results of the gravity equation model, showing the effects of SPS and other factors on the export value.

\section{Empirical issues}

Classical econometric problems of the model have tested, and the robustness of the model results tested against multicollinearity that may exist between the GDP and population variables. Hence, the population variables omitted in the second model is to mitigate the collinearity between GDP and population variables. As the result shows in the Table 6, the coefficient of, importing countries distance, official exchange rate, dummy variable, Sudan's production, domestic consumption, population, are robust, i.e. they maintain their sign and significance. The coefficient of the total aflatoxin level, though its significance changed, its sign is still negative like the first model [16-19].

Owed to robustness checks for the first model results and multicollinearity correction, we also removed importing countries GDP variables, besides excluding Sudan GDP. The Pooled EGLS method of multiple regressions used to estimate the behavior of groundnuts export value. The regression results have obtained using the (E-Views) package. The equation specified in a log-linear form, meaning that the estimated parameters correspond to the elasticity of exogenous variables with respect to changes in the groundnuts exports value. The elasticity for total aflatoxin level in the final model used to simulate export revenue, when using the CODEX regulation level [20].

\section{Empirical results and discussion}

The major empirical findings of the study model can interpreted as follow; there is a negative and statistically significant relationship between the dependent variable and the respective total maximum allowable aflatoxin level, domestic consumption and Sudan's population. Also there is a positive 
and statistically significant relationship between the dependent variable and the respective official exchange rate; dummy variable for the government effect; FOB price; distance and Sudan production of groundnuts for the gravity model. The decreasing

Table 6: Summary of the Empirical Findings and Results of the Gravity Regression.

\begin{tabular}{|c|c|c|c|c|c|c|c|c|c|}
\hline Predictors & Predictors & Predictors & Predictors & Predictors & Predictors & Predictors & Predictors & Predictors & Predictors \\
\hline LOG(OE) & 0.400261 & 8.864694 & $0.0000^{*}$ & $\begin{array}{l}\text { Included } \\
\text { in the } \\
\text { equation }\end{array}$ & LOG(OE) & 17.329127 & 25.79356 & $0.0000^{*}$ & $\begin{array}{l}\text { Included } \\
\text { in the } \\
\text { equation }\end{array}$ \\
\hline LOG(AF) & -0.201423 & -3.673154 & $0.0003^{*}$ & $\begin{array}{l}\text { Included } \\
\text { in the } \\
\text { equation }\end{array}$ & LOG(AF) & -7.144885 & -10.616616 & $0.0003^{*}$ & $\begin{array}{l}\text { Included } \\
\text { in the } \\
\text { equation }\end{array}$ \\
\hline DUM & 0.18555 & 1.932608 & $0.0543^{*}$ & $\begin{array}{l}\text { Included } \\
\text { in the } \\
\text { equation }\end{array}$ & DUM & 3.679666 & 5.426724 & $0.0543^{*}$ & $\begin{array}{l}\text { Included } \\
\text { in the } \\
\text { equation }\end{array}$ \\
\hline $\begin{array}{l}\text { LOG(POP }_{-} \\
\text {SUD) }\end{array}$ & -8.141301 & -10.15023 & $0.0000^{*}$ & $\begin{array}{l}\text { Included } \\
\text { in the } \\
\text { equation }\end{array}$ & $\begin{array}{l}\mathrm{LOG}^{\mathrm{PPOP}}- \\
\text { SUD) }\end{array}$ & -12.159159 & -14.168088 & $0.0000^{*}$ & $\begin{array}{l}\text { Included } \\
\text { in the } \\
\text { equation }\end{array}$ \\
\hline LOG(FOB) & 1.113004 & 28.74131 & $0.0000^{*}$ & $\begin{array}{l}\text { Included } \\
\text { in the } \\
\text { equation }\end{array}$ & LOG(FOB) & 56.369616 & 83.997922 & $0.0000^{*}$ & $\begin{array}{l}\text { Included } \\
\text { in the } \\
\text { equation }\end{array}$ \\
\hline $\begin{array}{l}\text { LOG(DC_ } \\
\text { SUD) }\end{array}$ & -14.43052 & -21.62045 & $0.0000^{*}$ & $\begin{array}{l}\text { Included } \\
\text { in the } \\
\text { equation }\end{array}$ & $\begin{array}{l}\text { LOG(DC_ } \\
\text { SUD) }\end{array}$ & -28.81038 & -36.00031 & $0.0000^{*}$ & $\begin{array}{l}\text { Included } \\
\text { in the } \\
\text { equation }\end{array}$ \\
\hline LOG(Y_SUD) & 14.7086 & 21.39863 & $0.0000^{*}$ & $\begin{array}{l}\text { Included } \\
\text { in the } \\
\text { equation }\end{array}$ & LOG(Y_SUD) & 28.08866 & 34.77869 & $0.0000^{*}$ & $\begin{array}{l}\text { Included } \\
\text { in the } \\
\text { equation }\end{array}$ \\
\hline LOG(D_BEL) & 16.39761 & 9.819046 & $0.0000^{*}$ & $\begin{array}{l}\text { Included } \\
\text { in the } \\
\text { equation }\end{array}$ & LOG(D_BEL) & 3.240482 & -3.338082 & $0.0000^{*}$ & $\begin{array}{l}\text { Included } \\
\text { in the } \\
\text { equation }\end{array}$ \\
\hline $\begin{array}{c}\text { LOG(D_ } \\
\text { BUL) }\end{array}$ & 17.20516 & 9.819046 & $0.0000^{*}$ & $\begin{array}{l}\text { Included } \\
\text { in the } \\
\text { equation }\end{array}$ & $\begin{array}{c}\text { LOG(D_ } \\
\text { BUL) }\end{array}$ & 2.432932 & -4.953182 & $0.0000^{*}$ & $\begin{array}{l}\text { Included } \\
\text { in the } \\
\text { equation }\end{array}$ \\
\hline LOG(D_FR) & 16.42032 & 9.819046 & $0.0000 *$ & $\begin{array}{l}\text { Included } \\
\text { in the } \\
\text { equation }\end{array}$ & LOG(D_FR) & 3.217772 & -3.383502 & $0.0000^{*}$ & $\begin{array}{l}\text { Included } \\
\text { in the } \\
\text { equation }\end{array}$ \\
\hline LOG(D_GB) & 16.28721 & 9.819046 & $0.0000^{*}$ & $\begin{array}{l}\text { Included } \\
\text { in the } \\
\text { equation }\end{array}$ & LOG(D_GB) & 3.350882 & -3.117282 & $0.0000^{*}$ & $\begin{array}{l}\text { Included } \\
\text { in the } \\
\text { equation }\end{array}$ \\
\hline $\begin{array}{c}\text { LOG(D_- } \\
\text { GER) }\end{array}$ & 16.49269 & 9.819046 & $0.0000 *$ & $\begin{array}{l}\text { Included } \\
\text { in the } \\
\text { equation }\end{array}$ & $\begin{array}{c}\text { LOG(D_ } \\
\text { GER) }\end{array}$ & 3.145402 & -3.528242 & $0.0000^{*}$ & $\begin{array}{l}\text { Included } \\
\text { in the } \\
\text { equation }\end{array}$ \\
\hline LOG(D_GR) & 17.58813 & 9.819046 & $0.0000^{*}$ & $\begin{array}{l}\text { Included } \\
\text { in the } \\
\text { equation }\end{array}$ & LOG(D_GR) & 2.049962 & -5.719122 & $0.0000^{*}$ & $\begin{array}{l}\text { Included } \\
\text { in the } \\
\text { equation }\end{array}$ \\
\hline LOG(D_IT) & 16.97427 & 9.819046 & $0.0000^{*}$ & $\begin{array}{l}\text { Included } \\
\text { in the } \\
\text { equation }\end{array}$ & LOG(D_IT) & 2.663822 & -4.491402 & $0.0000^{*}$ & $\begin{array}{l}\text { Included } \\
\text { in the } \\
\text { equation }\end{array}$ \\
\hline LOG(D_NL) & 16.356 & 9.819046 & $0.0000^{*}$ & $\begin{array}{l}\text { Included } \\
\text { in the } \\
\text { equation }\end{array}$ & LOG(D_NL) & 3.282092 & -3.254862 & $0.0000^{*}$ & $\begin{array}{l}\text { Included } \\
\text { in the } \\
\text { equation }\end{array}$ \\
\hline $\begin{array}{l}\text { LOG(D_ } \\
\text { POR) }\end{array}$ & 16.33701 & 9.819046 & $0.0000^{*}$ & $\begin{array}{l}\text { Included } \\
\text { in the } \\
\text { equation }\end{array}$ & $\begin{array}{l}\text { LOG(D_ } \\
\text { POR) }\end{array}$ & 3.301082 & -3.216882 & $0.0000^{*}$ & $\begin{array}{l}\text { Included } \\
\text { in the } \\
\text { equation }\end{array}$ \\
\hline LOG(D_SW) & 16.59808 & 9.819046 & $0.0000^{*}$ & $\begin{array}{l}\text { Included } \\
\text { in the } \\
\text { equation }\end{array}$ & LOG(D_SW) & 3.040012 & -3.739022 & $0.0000^{*}$ & $\begin{array}{l}\text { Included } \\
\text { in the } \\
\text { equation }\end{array}$ \\
\hline
\end{tabular}

order of importance is for the distance factor, then the factor for Sudan's domestic consumption; production and population. The SPS regulation is highly significant, suggesting sensitivity of groundnuts international competitiveness to aflatoxin level.

Source: Authors' own calculations. 
These results could be read as; the volume of groundnuts exports value would increase by about 0.40 percent in due response to one percent increase in official exchange rate; and by 1.113 in due response to one percent increase in FOB price; etc. The volume of groundnuts exports value would decrease by about 8.14 and 14.43 percent respectively in due response to one percent increase in Sudan population and domestic consumption. In addition, the volume of groundnuts exports value would increase by about $16.39,17.58$ percent in due response to one percent increase in distance (Table 7).

Table 7: Simulation Result of Adopting CODEX Recommendation by EU Countries and its Impact on the Trade Value of Sudan's Groundnuts Export (in US \$). Source: Authors' own calculations.

\begin{tabular}{|c|c|c|c|c|c|c|c|c|c|c|}
\hline \multirow[t]{2}{*}{ Year } & \multicolumn{2}{|c|}{ Belgium } & \multicolumn{2}{|c|}{ Belgium } & \multicolumn{2}{|c|}{ Belgium } & \multicolumn{2}{|c|}{ Belgium } & \multicolumn{2}{|c|}{ Belgium } \\
\hline & \multicolumn{2}{|c|}{$\begin{array}{l}\text { The Value of } \\
\text { Groundnuts import } \\
\text { (US\$ million) }\end{array}$} & \multicolumn{2}{|c|}{$\begin{array}{l}\text { The Value of } \\
\text { Groundnuts import } \\
\text { (US\$ million) }\end{array}$} & \multicolumn{2}{|c|}{$\begin{array}{l}\text { The Value of } \\
\text { Groundnuts import } \\
\text { (US\$ million) }\end{array}$} & \multicolumn{2}{|c|}{$\begin{array}{l}\text { The Value of } \\
\text { Groundnuts import } \\
\text { (US\$ million) }\end{array}$} & \multicolumn{2}{|c|}{$\begin{array}{l}\text { The Value of } \\
\text { Groundnuts import } \\
\text { (US\$ million) }\end{array}$} \\
\hline \multirow{3}{*}{ Average } & $\begin{array}{l}\text { Applying } \\
\text { Codex } \\
\text { standard }\end{array}$ & $\begin{array}{l}\text { Applying } \\
\text { Codex } \\
\text { standard }\end{array}$ & $\begin{array}{l}\text { Applying } \\
\text { Codex } \\
\text { standard }\end{array}$ & $\begin{array}{l}\text { Applying } \\
\text { Codex } \\
\text { standard }\end{array}$ & $\begin{array}{l}\text { Applying } \\
\text { Codex } \\
\text { standard }\end{array}$ & $\begin{array}{l}\text { Applying } \\
\text { Codex } \\
\text { standard }\end{array}$ & $\begin{array}{l}\text { Applying } \\
\text { Codex } \\
\text { standard }\end{array}$ & $\begin{array}{l}\text { Applying } \\
\text { Codex } \\
\text { standard }\end{array}$ & $\begin{array}{l}\text { Applying } \\
\text { Codex } \\
\text { standard }\end{array}$ & $\begin{array}{l}\text { Applying } \\
\text { Codex } \\
\text { standard }\end{array}$ \\
\hline & Assumed & (US\$) & Assumed & (US\$) & Assumed & (US\$) & Assumed & (US\$) & Assumed & (US\$) \\
\hline & $\begin{array}{l}\text { trade value } \\
\text { (US\$) }\end{array}$ & & $\begin{array}{l}\text { trade value } \\
\text { (US\$) }\end{array}$ & & $\begin{array}{l}\text { trade value } \\
\text { (US\$) }\end{array}$ & & $\begin{array}{l}\text { trade value } \\
\text { (US\$) }\end{array}$ & & $\begin{array}{l}\text { trade value } \\
\text { (US\$) }\end{array}$ & \\
\hline $1980-1989$ & $1.4 \mathrm{E}+08$ & 39400 & $1.4 \mathrm{E}+08$ & 420000 & $1.4 \mathrm{E}+08$ & 4462300 & $1.4 \mathrm{E}+08$ & 5460500 & $1.4 \mathrm{E}+08$ & 2584300 \\
\hline 1990-1999 & $1.9 \mathrm{E}+08$ & 77000 & $1.9 \mathrm{E}+08$ & 191900 & $1.9 \mathrm{E}+08$ & 347500 & $1.9 \mathrm{E}+08$ & 1180300 & $1.9 \mathrm{E}+08$ & 276900 \\
\hline $2000-2010$ & $2.6 \mathrm{E}+08$ & 19500 & $2.6 \mathrm{E}+08$ & 133600 & $2.6 \mathrm{E}+08$ & 16300 & $2.6 \mathrm{E}+08$ & 881900 & $2.6 \mathrm{E}+08$ & 238900 \\
\hline Total & $5.8 \mathrm{E}+08$ & $5.8 \mathrm{E}+08$ & $5.8 \mathrm{E}+08$ & $5.8 \mathrm{E}+08$ & $5.8 \mathrm{E}+08$ & $5.8 \mathrm{E}+08$ & $5.8 \mathrm{E}+08$ & $5.8 \mathrm{E}+08$ & $5.8 \mathrm{E}+08$ & $5.8 \mathrm{E}+08$ \\
\hline $\begin{array}{l}\% \text { Change } \\
\text { from the } \\
\text { actual } \\
\text { trade } \\
\text { value }\end{array}$ & 344132 & 344133 & 344134 & 344135 & 344136 & 344137 & 344138 & 344139 & 344140 & 344141 \\
\hline
\end{tabular}

The result implies that a 10 percent tightening of the aflatoxins standards (a 10 percent smaller maximum level of contamination) will reduce groundnuts exports value by 20.14 percent. The magnitude of the effect is greater reflecting a greater sensitivity of groundnuts trade to aflatoxin standards. Similarly, magnitude of groundnuts production coefficient means; relative increase in production of groundnuts by one percent, when holding other factors constant, groundnuts exports value would increase by 14.708 percent. The signs of all the estimated coefficients are compatible with a priori theoretical explanations except the sign of distance. The sign of the Sudan's population is negative indicating less production also the results suggest that increased population of Sudan does not increase the foreign and bilateral trade with EU, the negative sign may also reflect the absorption or economies of scale effects. Larger countries have a greater capacity to absorb productions than do their smaller counter parts.

The explanatory variables were significantly different from zero at $5 \%$ level of significance. These results were as expected. Nevertheless, regression coefficient of cost factor associated with distance, contrary to a prior expectation, the key findings there is positive correlation between the exports value of groundnuts and the relative distance. We expect the coefficient to be negative. Nevertheless, given the little variability observed in this variable, it is quite possible that the coefficient on distance could be capturing some other effect that the model is failing to identify correctly; also, the recent development in transport and transaction procedures may overpower the true effect of the cost factor.

$\mathrm{R}^{2}$ which implies the coefficient of multiple determination shows that the included explanatory variables explain about 98\% (adjusted R square $=98 \%$ ) of the variation in the dependent variable. The regression analysis of groundnuts exports value has been able to explain more than $98.3 \%$ of the factors affecting the value of groundnuts exported to EU. Serial correlation is not found in the model, as indicated by the value of Durbin Watson, which is 2.219106, showing that the null hypotheses of the absence of serial correlation falls within the acceptance region [21].

F-statistic which provides the overall significance of the model shows that the model is statistically high significant at $5 \%$ level of significance. Indicating real relationship between dependent and independent variables, also it means the model fit the data and highly significant in explaining the variations in groundnuts exports value. T-value is highly significant for aflatoxin infection level and for the other incorporated variables. From this analysis it is evident that the total aflatoxin level; 
official exchange rate; FOB price; distance and government effect Sudan's domestic consumption; production and population; are the major determinants of groundnuts exports, their high and strongly significant coefficients suggest a strong responsiveness of groundnuts exports value to changes in them. This, stress their vital role in determining exports of groundnuts in Sudan [22,23].

\section{Implications of the findings}

Judging by the overall statistical and econometric diagnostic tests i.e. T- statistic, F- statistic, R squared, Adjusted R squared, and Durbin Watson, the estimated coefficients are statistically different from zero, and no presence of serial correlation. The results suggest that a low level of maximum aflatoxin standard of EU does not increase the bilateral trade with Sudan.

The exports value of groundnuts crops affected much stronger by external factors represented in large and high significant coefficient of distance, FOB price and total aflatoxin level. Thus, importing countries adopted total aflatoxin level is significant factor that affect the groundnuts trade values. The SPS standard with significant and high coefficient magnitude confirmed the sharp plunges in the value of groundnuts exported to EU during the last decade; this result could explained by the implementation of the EU new stringent aflatoxin regulations. In sum, results show that SPS regulations do matter considerably in groundnuts seed trade.

In addition, the results so far suggest that groundnut exports value has suffered from internal factors represented in the official exchange rate, Sudan's domestic consumption; production, population and government effect, which in turn reflect influence of many environmental and domestic policies. Despite the persistent efforts by the government to liberalize trade it continue to suffer from intervention. Hence, for better performance for this sector; The Sudan would have to succeed in reversing the declining trend in productivity and provide national sectors with better incentives for export.

The findings of the study also highlight the crucial importance of internal factors in determining competitiveness and profitability of groundnuts and shed light on importance of improving the present macroeconomic reform policies that encourage groundnuts producers to increase the output of groundnuts for the domestic and export markets. This would entail the stability of foreign exchange rates, removal of farm, market and export taxes, etc.

\section{Simulation results of applying CODEX recommended standard by EU countries on sudan groundnuts exports}

This section simulates effects of various policy interventions on groundnuts exports, it provides results on how trade flows between Sudan and Europe would differ under two regulatory scenarios in which (1) The EU harmonizing its standard under the CODEX guidelines and (2) EU Commission's new standard, that exceeded the recommendations of such international standard-setting body.
The predicted trade flow in value under both conditions computed. As noted, CODEX set the standards on total aflatoxin level at (15ppb); The SPS elasticity obtained from the gravity equation of export value used in the simulations.

By using the final models, as shown in Table 6, value of groundnuts exhibit a significant difference between the two scenarios. Among the EU countries, Britain alone estimated to have an increase in imports under the codex standards by 7658 percent, since it had a lower aflatoxin standard level prior to 1998. In addition, under the codex standards France, Netherlands estimated to increase groundnuts imports by the largest magnitude of 11994 and 6368 percent respectively, from the assumed trade value based on the (1980-2010) groundnuts trade.

In the codex scenario, the predicted trade flow earnings (value) of groundnuts during (2000-2010) - that means during the applied Commission's new standard- is US\$2,558,319,102, which is 98,844 percent than the actual trade value of EU, which is US $\$ 2,585,620$. This assumed level of CODEX standard trade value implies considerable trade loss and high damage generated by the new EU restrictive standard. Remarkably, under the less stringent Codex standard the increase of the trade flow is considerably higher relative to the second scenario, indicating trade expansion and suggesting that exports to EU may increase significantly if SPS barriers reduced. Hence, it found that the Commissions standard would impose a considerable loss of export revenue in Sudan. In particular, the Commission's standard will impose far greater trade impediments when compared with trade under an international standard for groundnuts and edible nuts trade. Therefore, it may argued that from the exporter perspective the damage and loss generated by the new restrictive EU standard is substantial.

The simulation results suggest that there are considerable assumed (expectation) gains to make if all the EU countries included in the study were to apply the aflatoxin level recommended by CODEX. Then, Sudan would have gained an estimated additional groundnuts export earnings (value) ranged between 344132 to 6368 percent from 1980 to 2010. That is on average a loss of over $175250 \%$ above the 2010 export earnings from groundnut exports. Due to the stringent standards applied by these countries, however, this amount represents the forgone export revenues for Sudan. In general, the simulation results provide further evidence of the potential increase in revenues if SPS barriers reduced [24-26].

\section{Implications of the findings}

There are expected benefits for Sudanese groundnuts exports under the CODEX SPS regulations. The benefits to groundnut exports under WTO measures come from the fact that they avail more fair competition for Sudan groundnut exports. If the government removes the taxes and the importing countries reduce aflatoxin standards to ease market access, which is one 
of WTO [5] provisions, exports to EU and international market access opportunities for exporters may increase significantly via the elimination and reduction of SPS barriers. The price and volume of groundnuts exports expected to rise, such arise if allows transmitting to producers, should help raise domestic production, resulting in the improvement in farmer's income, trade balance and the overall growth of the economy. This would verify the potential ability of Sudan groundnuts exports to reap greater benefits when EU applies the Codex standards.

In addition, the Sudan may not be able to find alternative markets outside Europe away from its high dependency on the European market. It will then have to choose whether to bear higher costs for transportation and accession to new markets or to invest in compliance to the new standards to avoid trade losses. This simulation also does not consider the Sudan's potential benefits from compliance. If Sudan is able to comply with the European standards, liver cancer deaths of its population would decrease as well. These benefits are supposed to offset the export losses. The WHO fined that the EU's new aflatoxin standard would dramatically reduce imports from poor countries while having essentially no impact on the health of EU consumers. While these issues are of great interest, they are beyond the scope of this simulation analysis.

To facilitate trade, countries are encouraged to use relevant international standards and work towards harmonization that is, the adoption of common SPS measures. To promote harmonization, the WTO [5] agreement cites, as sources of scientific expertise and globally recognized standards for food safety, Codex aliment Arius. In the groundnuts exporting sectors, it is unlikely that the measures taken by EU importing countries could said to have been taken as a protectionist device to provide protection for home producers and suppliers, since the produce under consideration poses no competition threat to them.

The foregoing discussion suggests a need for shifting of focus to policies aimed at enhancing the productivity, efficiency, value addition and cost reduction particularly in agricultural activities to reverse current trade deficit levels, debt burden and poverty. This second set of generation of policy actions are necessary and timely to boost export earnings by addressing constraints to exporting along the supply-distribution-marketing chain in order to exploit new market opportunities and in products whose demand is income elastic. Such actions are essential in enhancing the competitiveness of dynamic and promising products with great potential for contributing to export earnings, employment creation, income generation and poverty reduction in Sudan.

\section{Conclusion and Policy Implications}

\section{Conclusion}

This study revealed a set of conclusions. SPS trade barriers affecting Sudan groundnuts and limit the amount of its exports or impose additional costs on Sudan groundnuts producers and exporters, hence, reducing the groundnuts industry revenue for the Sudan. Thereby, Sudan needs to quantify the importance and impact of food safety issues. The demand for better estimates of the impact of these regulations on trade is emerging among policy makers. Such domestic regulations may constitute major trade impediments and their use is proliferating. In order for developing countries to benefit more fully from the opportunities offered by international markets, they need to address food safety issues and comply with the provisions of the SPS Agreement. The conclusion of the study has the following major policy implications:

\section{Policy implications}

Aflatoxin infection is the most important factor that affects groundnuts exports in the recent years, particularly exports to European common market. Thus, the main policy implication of this study is that stringent SPS standards set by developed countries have a potential to offset the perceived gain of liberalizing agricultural trade. The study also politically implies that Sudan has vast areas under groundnuts crop production that geared towards more expanded export opportunities if the domestic policies in the Sudan reformed to take advantage of the opportunities open to it.

Exploiting the market access opportunities under various trade arrangements and agreements depends critically on the country's ability to overcome stringent and dynamic market entry constraints, including complying with food safety and health regulations or standards in the importing markets. The authors have obtained results suggest several areas for consideration in a public policy context. Based on these results, the following policies could draw:-

A. Sudan should seek more access to the international markets for its groundnuts exports.

B. The future of Sudan's policies in the area of sanitary and phytosanitary measures should be monitored in order to be consistent with the new WTO disciplines and at the same time serve its future developmental aims.

C. Sudan should review and analyses the SPS regulations of its trading partners, so as to benefit from potential regional and international market opportunities.

D. Policies required maintained and issued to enable the country to strengthen the agricultural sector and protect it through rules that comply with the WTO provisions.

E. In order to mitigate potential negative impacts of groundnuts health measures and food safety; Sudan need to identify and implement policies to enhance sustainable income opportunities for small farmers, in particular resource-poor ones $[27,28]$.

\section{References}

1. Becker GS (2006) Sanitary and Phytosanitary (SPS) Concerns in agricultural trade. Congressional Research Service, the Library of Congress. 
2. Authokorala P (2004) Food safety issues, trade and wto rules: a developing country perspective. International Workshop on International Food Safety Regulation and Processed Food Exports. New Delhi, India, pp. 27-28.

3. Thornsbury S (1998) Technical regulations as barriers to agricultural trade. PhD dissertation, Virginia Polytechnic Institute, Virginia, USA.

4. WTO (2000) The sps agreement-matters of particular interest to african countries. Background document, MM/LIB/WS6/3.

5. John AM (1999) Benefits and costs of food safety regulation. food policy 24. Technical Bulletin No. 1876, U.S. Department of Agriculture, Economic Research Service, Washington DC, USA, pp. 605-623.

6. Asopa VN (2003) Competitiveness in pineapple canning industry. Hawaii International Conference on Bussiness. Honolulu, Hawaii, USA, pp. 18-21.

7. Bergstrand, Jeffrey $H$ (1985) The gravity equation in international trade: some microeconomic foundations and empirical evidence. The Review of Economics 67(3): 474-481.

8. Boom A (1995) Asymmetric international minimum quality standards and vertical differentiation. The Journal of Industrial Economics 43(1): 101-19.

9. Linda C, Krissoff B (1998) Technical barriers to trade. a case study of phytosanitary barriers and us- japanese apple trade. Journal of Agricultural and Resource Economics 23(2): 351-366.

10. Sohn CH (2005) Does the gravity fit the korea's trade pattern? Korea Institute for International Economic Policy, Yokohama National University, Yokohama, Japan.

11. Cheng I, Hu I, Howard J, Wall (2005) Controlling for heterogeneity in gravity models of trade and integration. In: Claudio E, Montenegro, Isidro, Soloaga (Eds.), NAFTA'S Trade Effects, New Evidence with a gravity Model, Estudios Do Economia 33: 45-63.

12. Russell D, James G, MacKinnon (1993) Estimation and inference in econometrics. Oxford University Press, New York, USA.

13. Disdier AC, Fontagné, Mimouni M (2008) The impact of regulations on agricultural trade. evidence from sps and tbt agreements. American Journal of Agricultural of Economics 90(2): 336-350.

14. Harris Mark A, Matyas L (1998) Econometrics of Gravity Model. Melbourne Institute Working Paper 98(5).

15. Henson S, Loader R, Swinbank A, Bredahl M, Lux N (2000) Impact of sanitary and phytosanitary measures on developing countries. Department for International Development, London.
16. Henson S, Loader R (2001) Barriers to agricultural exports from developing countries. The Role of Sanitary and Phytosanitary Requirements 29(1): 85-102.

17. Henson SJ, Loader R, Swinbank A (1999) The impact of sanitary and phytosanitary measures on developing country exports of agricultural and food products. Paper presented at the World Trade Organization meeting, Agriculture and the New Trade Agenda from a Development Perspective. Geneva, Switzerland.

18. Hooker NH (1999) Food safety regulation and trade in food products. food policy. in quantifying trade effect of technical barriers. can it be done? In: Maskus KE, Wilson JS, Ann Arbor (Eds.), University of Michigan Press, USA.

19. Stepan J (2002) Econometrics of panel data and limited dependent variable model. Lecture Notes Series Charles University Czech Republic, USA.

20. Sallie J, Andeson K (1998) On the need for more economic assessment of quarantine/sps policies. Centre for International Economic Studies, University of Adelaide, Australia.

21. Jane K, Melatos M, Rau M (2008) A review of methods for quantifying the trade effects of standards in the agri-food sector.

22. Lux N, Henson SJ (2000) The impact of food safety and quality standards in eu cheese exports to the united states. Department of Agricultural and Food Economics, The University of Reading, England.

23. Masku KE, Wilson JS, Otsuki T (2001) An empirical framework for analyzing technical regulations and trade.

24. Peter S, Temple P, Shurmer M (1996) Standards and trade performance. The UK Experience, Economic Journal 106: 1297-1313.

25. Vido E, Prentice B (2001) Methodological issues in gravity model analysis with applications to canadian pork and lentil trade. Paper presented at American Agricultural Economics Association annual meeting, Chicago, pp. 5-8.

26. Waniala N (2000) Impact of sps measures on uganda fish exports. PSF/ Trade Policy Capacity Building Project.

27. Wilson, John S (2000) The development challenge in trade: sanitary and phytosanitary standards. World Trade Organization, Geneva, Switzerland.

28. World Bank (2008) World development report 2008: agriculture for development. The World Bank, USA.

\section{Your next submission with Juniper Publishers will reach you the below assets}

- Quality Editorial service

- Swift Peer Review

- Reprints availability

- E-prints Service

- Manuscript Podcast for convenient understanding

- Global attainment for your research

- Manuscript accessibility in different formats

( Pdf, E-pub, Full Text, Audio)

- Unceasing customer service

Track the below URL for one-step submission https://juniperpublishers.com/online-submission.php 